DOI: 10.2478/ausfm-2019-0002

\title{
German Expressionism in Context: the First World War and the European Avant-Garde
}

\author{
Ian Germani \\ University of Regina (Canada) \\ E-mail: Ian.Germani@uregina.ca
}

\begin{abstract}
German Expressionism, although often viewed as a uniquely German phenomenon, was part of a broader crisis affecting the European avant-garde at the time of the First World War. The experience of modernity, so proudly displayed at events like the Universal Exposition of 1900, inspired both hopes and fears which were reflected in the works of artists, writers and musicians throughout Europe. The outbreak of the war was welcomed by many exponents of the avant-garde as the cathartic crisis they had anticipated. The letters and diaries of artists who hastened to enlist, however, reflected their rapid disillusionment. The war had the effect of severing cultural ties that had been forged prior to 1914. This did not prevent a parallel process of cultural evolution on both sides of the conflict. Those who survived the war, of diverse nationalities and artistic affiliations, produced works reflecting a common perception that modern civilization had resulted in humanity becoming a slave to its own machines.
\end{abstract}

Keywords: avant-garde, Expressionism, First World War, art, modernism.

\section{Belle Epoque and Fin de Siècle}

Although the subject of this special issue is German Expressionism, this article begins by considering a painting produced not by a German, but by a Frenchman, and which can be viewed at the Museum of Modern Art of the City of Paris, itself located in the Palais de Tokyo, a building constructed for the Universal Exposition of 1937. The building's esplanade offers a splendid view of the Champ de Mars and the Eiffel Tower. The painting is Robert Delaunay's L'équipe de Cardiff, which was exhibited at the Salon des Indépendants in 1913. [Fig. 1.] There could hardly be a more appropriate setting for this painting, which represents not only the Eiffel Tower, inaugurated at the Universal Exposition of 1889, but also the Ferris wheel 
that was a legacy of the Universal Exposition of 1900. Visually, it is the Ferris wheel that provides the link between the upwards leap of the rugby player in the foreground of the painting to the biplane - actually a Wright flyer, the aircraft developed by the Wright brothers - in the sky above. Advertising hoardings promote Astra - the company that manufactured the Wright Flyer in France - as well as Delaunay himself, reminding us that the artist's reputation reached at least as far as New York. Robert Wohl, describing an earlier version of the painting, exhibited in Berlin in 1912, writes: "assaulted by this wealth of imagery, which we are supposed to assimilate simultaneously as a whole, we understand intuitively that Paris is the capital of technology [...] and that the twentieth century is one of ascension and movement upwards toward the stars - ad astra" $(1994,188)$.

Not everybody liked L'équipe de Cardiff. Delaunay sent a photograph of it to Franz Marc, one of the leading German Expressionist painters, who dismissed it as "the sheerest Impressionism, instantaneous, photographic motion [...]. The only thing that struck me about the picture is that it is very Parisian, very French, but very far removed from my ideas" (Wohl 1994, 190). Delaunay wrote back to say, "with this picture, which is the most perfect and beautiful subject, I have outdone myself [...]. It is the most important, the very newest picture theme in my art and at the same time the most representative in its execution" (Wohl 1994, 192). Indeed, with its bright colours, harmonious symmetries and literally uplifting themes, the painting encapsulates the confidence of an era which would come to be defined as a Belle Epoque. L'équipe de Cardiff is a feel-good painting that expresses the confidence of an age of progress.

Very different was another painting which was also completed in 1913, this time by a German artist. Max Beckmann's vast canvas representing the disaster of the sinking of the Titanic, on the night of 14-15 April, 1912, was a commentary on the hubris of those who put their faith in modern technology. [Fig. 2.] The painting depicted the famous ship and the iceberg that sank it in the background, while in the foreground it represented the desperation of men and women fighting for a place in the boats. "Beckmann," writes Emilio Gentile, "wished to evoke the tragic condition of human existence during the epoch of triumphant modernity." (2011, 214, my translation). The painting was "a prophetic reminder" of human vulnerability. It is anything but a feel-good painting, but in its way it was as emblematic of the mood of Europe in 1913 as was that of Delaunay. At that time there were many writers and artists who warned that modern civilization, corrupted by the very forces that had ensured its triumph, was on the brink of a catastrophe. Indeed, not a few were openly contemptuous of the decadence which 
they believed modernity and material progress had brought in their wake and looked forward to a regenerative apocalypse. Whether through war, revolution, or a general cultural upheaval, the impending catastrophe would sweep away the old world and liberate the creative forces of a new man. The cultural pessimism exemplified by Beckmann and given literary expression by Friedrich Nietzsche embodied the spirit not so much of a confident Belle Epoque, but of an anxious Fin de Siècle. The connection between Nietzsche and the Expressionists is unquestionable. The group of Expressionists who identified themselves as Die Brücke (The Bridge) took its name from a passage in the prologue to Thus Spoke Zarathustra in which Nietzsche defined man as a rope or a bridge over an abyss, "between beast and overman" (Eliel 1989, 17).

The paintings by Delaunay and Beckmann embody two contrasting representations of and attitudes toward modernity - attitudes that jostled for precedence with one another throughout the two decades preceding the First World War. We might be tempted to contrast them in terms of national styles, to agree with Marc about the Delaunay that it is "very French, very Parisian," and to say likewise of the Beckmann that it is very German. European avant-garde movements are often defined by nationality. We speak of German Expressionism, Italian Futurism, French Cubism, British Vorticism, Russian Suprematism and, for the postwar period, of German New Objectivity and French Surrealism. At times, there appeared to be a gulf of incomprehension between these movements. Delaunay confessed himself to be as baffled by the mysticism that animated the young German painters as Marc was by Delaunay's L'équipe de Cardiff (Vriesen and Imdahl 1967, 57-58). Yet it is revealing that Delaunay first exhibited his painting in Berlin and that he persisted in his frank correspondence with Marc, with Auguste Macke and Ludwig Meidner, as well as with other German artists who visited him in his Paris studio. His painting of the Équipe de Cardiff itself pointed to the way the forces of modernity were bringing the world's great cities, like New York and Paris, closer together. "In Berlin, I did not feel like a foreigner, except for the language," wrote Delaunay after his 1913 visit. "Berlin is luminous" (Vriesen and Imdahl 1967, 57-58). Before 1914, the metropolises of London, Rome, Paris, Berlin, and Vienna drew artists to them like moths to a flame. It was to these cities, which concentrated the essence of modernity, for good or ill, that artists came in search of ideas and inspiration. In Emilio Gentile's words, "they discovered and recognized their spiritual brothers in the heart of a young European community of creators of new art" (my translation, 2011, 243). Thus, the young Max Beckmann, as soon as he had finished his training as an artist in Weimar, 
headed off to Paris, very much the capital of the international art world. In a point form autobiography written in 1924, he would write "Beckmann undertook his education as a European citizen in Weimar, Florence, Paris and Berlin" (2002, 201). In 1909, he added his voice to those of seventy-four other German artists who rejected the argument of Carl Vinnen that "a people can only be lifted to the heights by artists of its own flesh and blood" and that German art galleries should therefore adopt protectionist acquisition policies. (Beckmann 2002, 118.) In his own writing, Beckmann's admiration for Cézanne, Signorelli, Tintoretto, El Greco, Goya, Géricault and Delacroix was unconstrained by nationalism. As Count Harry Kessler said of him, Beckmann was "German, but fully recognizing the debt to the French, especially Cézanne and Gauguin and Maillol. He has spent half a year in Paris and clearly observed and learned much there" (2011, 370).

Europe's avant-garde artists therefore shared a great deal in common prior to the First World War, not least their ambivalent relationship to modernity. The war threatened to divide them against one another, just as it severed the international ties that had proved so fruitful prior to 1914. In 1912, Harry Kessler had gone with the Russian impresario, Sergei Diaghilev, to the home of Auguste Rodin, to offer their support to the French sculptor and his American mistress after Rodin had been attacked in the conservative press because of his enthusiasm for Diaghilev's controversial modernist troupe, the Ballets Russes. "We sat around him in his bedroom," wrote Kessler, "a Russian, a German, and an American, to console the old Frenchman" (2011, 601). Eight days before the war began, however, Kessler had escorted Rodin from London to Paris as he himself returned to Germany, waving goodbye to his friend at the Gare du Nord. "I already knew that I would never see him again," Kessler wrote in his diary when he learned of Rodin's death in November 1917 (2011, 792). The severing of such friendships within the avant-garde community was not without consequences. French Cubism, in particular, was a victim of war-time xenophobia. Nevertheless, even if a result of the war was the emergence of the very different New Objectivity movement in Germany and Surrealism in France, the similarity of their experiences during the war meant that the relationship of the two countries' avant-gardes with modernity underwent a parallel evolution. The war made real a catastrophe that many had predicted but one that dashed their hopes of regeneration. Instead, it confirmed a much darker vision of modernity's starkly dehumanizing consequences, as humans became the slaves of machines. After the war, artists and intellectuals throughout Europe once again drew inspiration from one another, expressing their indignation at the war and at the modernity the war embodied. 


\section{Modernity on Display: Paris and Berlin}

The high point in Europe's celebration of modernity was without doubt the Universal Exposition held in Paris in 1900, an occasion which drew fifty million people from all over the world to witness 83,000 exhibits of the latest accomplishments of science and technology. The Exposition highlighted the transformative power of electricity. The giant dynamos in the Palace of Electricity, which were used to illuminate the Eiffel Tower, inspired a religious reverence in the American visitor, Henry Adams, who wrote that he experienced the forty foot dynamos as "a symbol of infinity [...], a moral force, much as the early Christians felt the Cross [...]. Before the end, one began to pray to it; inherited instinct taught the natural expression of man before silent and infinite force” $(1918,205)$. The force of electricity was intrinsic to the experience of visitors to the Exposition. It illuminated the Exposition at night and powered the moving sidewalk that linked its venues, as well as the electric train which circulated along the same route as the sidewalk but in the opposite direction (Le Petit Journal 29 April 1900). The new divinity was not omnipotent, since the Exposition experienced numerous short-circuits and power failures. The Petit Journal noted that the illumination of an artificial waterfall was only a partial success; as the waterfall brightened so the lights in local restaurants dimmed (Le Petit Journal 14 May 1900). Nonetheless, the Exposition reaffirmed the primacy of France as the heartland of modernity. In his speech at the opening ceremony, President Loubet proudly evoked the achievement of Louis Pasteur in discovering the bacteriological causes of disease. "Death itself recoils before the victorious achievement of the human mind," he declared (The Times 16 April 1900). The French claimed to be at the forefront of progress on many fronts. It was the Lumière brothers and Pathé films who led the way in the new film industry, which was rapidly making its presence felt throughout the world as a popular entertainment. It was French inventors, such as André and Edouard Michelin and Armand Peugeot who had pioneered the development of the bicycle as a vehicle of mass leisure and transportation - there were three and a half million bicycles in France by 1914 - before doing the same for the motor car (Weber 1986, 197-207). As the number of automobiles grew, accidents became more frequent and the first speed limits were imposed. The Petit Journal warned in 1900 that over-regulation of automobiles might lead to the emigration of a "national industry" ("industrie nationale" - Le Petit Journal 3 May 1900) and the loss of thousands of jobs. A 1907 French guidebook provides ample evidence that such concerns were not well founded, taking perverse pride 
that more pedestrians were run over by cars on Paris streets than on those of any other city of the world (Levenstein 1998, 134). The French had also surpassed themselves in the pioneering of aviation. It was French pilots who were the first to fly across the English Channel (1909) and from Paris to Rome (1911). The Eiffel Tower, lit up for the exposition of 1900, was subsequently given a new lease on life as a symbol of modernity - and of Paris as the heartland of that modernity as it was repurposed as a radio tower. In July 1913, it became "the watch of the universe," emitting a powerful signal twice a day for the world to set its clocks by (Emmerson 2013, 45).

Despite such evidence that France was on the cutting edge of the new technologies that were transforming industry, communication and transportation, the French press commented grudgingly on the success of Germany's exhibits at the Exposition of 1900. The Petit Journal, noting that Germany had hardly figured in the Exposition of 1889, reported the interest aroused by the display of scale models of German battleships: "the public stands for a long time before these toys that represent enormous factors of destruction" (my translation, Le Petit Journal 16 May 1900). Another French writer pointed to the four great dynamos in the Palace of Electricity and a mobile crane capable of lifting a weight of thirty tons as evidence of the "ever ascending march of Germany toward the summit of industry" (my translation, L'Exposition en Famille: Revue illustrée de l'exposition universelle de 19005 June 1900, 151). Germany, a late starter in terms of its modernization, had leap-frogged its rivals. Berlin, capital of the new German Empire created in 1871, had swelled from 200,000 inhabitants in 1813 to nearly four million a hundred years later. While it may not have been in a position to challenge the status of Paris as the capital of culture - indeed its critics disparaged it as "Chicago on the Spree" - Berlin's credentials as the capital of science and technology were unrivalled. Not only did Berlin possess leading technical institutes and universities, such as the Kaiser Wilhelm Institute for the Advancement of Science, which became the home of Albert Einstein at the end of 1913, but it could also boast industrial giants like Siemens and AEG. Berlin dominated Europe's chemical and electrical engineering industries. The city's trams and railway system were unequalled. The tramways were fully electrified by 1902 . The above ground city railway, the Stadtbahn, was launched in 1882, and work began on an underground railway in 1896, four years before the first Paris metro line opened. Berlin never hosted a Universal Exposition, but in 1896 it did provide a venue, at Treptower Park, for an Industrial Exposition which covered a larger area than any previous exposition and which included a Hall of Appetite where could be seen such marvels of 
modernity as a giant sausage making machine (Large 2000, 82). Walther Rathenau, the head of AEG, self-deprecatingly referred to Berlin as the "parvenu of Great cities and a Great City of parvenus" (Large 2000, 48) but, as Charles Emmerson sums up: "while Paris might retain the crown of the cité lumière, Berlin gloried in the title of 'Elektropolis,' city of electricity” (2013, 62).

The effects of modernization, so proudly displayed in cities like Paris and Berlin, were mixed. On the one hand, confidence in European superiority and in the future was enhanced. Delaunay's painting conveyed the message of those who put their faith in modernity that, quite literally, the sky was the limit. On the other hand, modernity brought in its train unanticipated changes that were a source of anxiety. Berlin's expansion was accompanied by the creation of a vast, impoverished working class, many of them living in frightful conditions in infamous rental barracks, others in cardboard shelters that proliferated around the city gates and which the authorities periodically razed. Socialism made rapid progress among this constituency and in 1912 the Social Democratic Party won 75.3\% of votes in the elections to the Reichstag (Large 2000, 104). Strikes and demonstrations were common. In France, too, socialists and trade unionists were increasingly militant, clashing regularly with police in May Day demonstrations. In both France and Germany, military insecurity produced contradictory results. In Germany, the military camarilla that surrounded the Kaiser aggressively asserted Germany's status as a world power. The sabre was famously rattled on a number of occasions, most notably during the Morocco Crises of 1905 and 1911. German workers responded by demonstrating for peace. 200,000 protested in Berlin's Treptower Park against their government's actions during the crisis of 1911. Similarly, in France, where fears about the decline of the French population relative to Germany's encouraged the government in 1913 to extend the period of military service from two years to three, massive demonstrations were organized by socialist and trade union leaders on the outskirts of Paris. The Bataille Syndicaliste estimated 200,000 participants - "200,000 hearts that beat in unison" against "the patriotic madness" (my translation, La Bataille Syndicaliste 17 March 2013) - for the 16 March demonstration held on the Pré-Saint-Gervais against the three-year law. But the "patriotic madness" had its advocates, too. In 1913, two young Frenchmen, Henri Massis and Alfred de Tarde, published a work entitled The Young of Today, in which they condemned the decadence of the older generation, insisting that the new generation to which they belonged was imbued with a new spirit, one that rejected the conformism and materialism of the modern world, embracing instead the values of action, patriotism and self-sacrifice: values that could only be fulfilled through war. The authors cited approvingly the words of 
Ernest Psichari, whose rediscovery of Catholic and patriotic ideals, as well as of more primitive, warlike values, derived from his experiences fighting Arab tribesmen in the deserts of North Africa: "from an extreme barbarity we have moved on to an extreme of civilization [...]. But who knows if, by a reversal that is not uncommon in human history, we may not come back to the place from which we departed? A time is coming where even goodness ceases to be fruitful and becomes weakening and cowardly" (my translation, Agathon 1919, 34).

There is little wonder, then, that the artists and intellectuals who inhabited Europe's capitals had a love-hate relationship with the modern city. Ludwig Meidner, in encouraging his fellow artists to make the city the subject of their art, wrote, "we must finally begin to paint our homeland, the metropolis, for which we have an infinite love [...]. Let's paint what is close to us, our city world! The wild streets, the elegance of iron suspension bridges, gas tanks which hang in white-cloud mountains, the roaring colors of buses and express locomotives, the rushing telephone wires [...], the harlequinade of advertising pillars, and the night [...] big city night" (Large 2000, 73). And yet this professed love for the city expressed itself in Meidner's art in images of urban catastrophe, such as his Apocalyptic Landscape and Burning City, both produced in 1913. "I cried out inwardly for the far-off rattle and the trumpet blasts of future catastrophes," Meidner wrote later, looking back at his state of mind as he plunged into his most intense phase of apocalyptic creativity. "Did I not crave comet-trails and blazing volcanoes in every background?" (Roters 1989, 70.) The exuberant chaos of the modern city inspired foreboding and visions of the apocalypse.

In his apocalyptic city-scapes Meidner was in tune with the spirit of the age. Whether in the philosophy of Friedrich Nietzsche or the poetry of Georg Heym and Hugo von Hofmannsthal, in the theosophical writing of Rudolf Steiner, in the fiction of Andrej Belyj and H.G. Wells, in the music of Scriabin and RimskyKorsakov, in the painting of Wassily Kandinsky and Franz Marc, apocalyptic ideas were in every medium and every place. Encapsulating this apocalyptic mood as well as several different media was Sergei Diaghilev's production of the ballet, Rite of Spring, notoriously performed for the first time - and prompting a near riot - at the Théâtre des Champs-Elysées in Paris on 29 May, 1913. Stravinsky originally proposed the title of The Great Sacrifice for this composition, which, through the violent choreography of Nijinsky and the dissonant, primal rhythms of Stravinsky's music, told the story of a pagan ritual in which a young virgin dances herself to death. The ballet captured what Emilio Gentile has described as the "yearning for sacrifice" on the part of the new generation, "which scorned the belle époque of 
triumphant modernity and called for a war or a revolution that would destroy a world which appeared old and corrupt, in order to give birth to a new world and a new man” (my translation, 2000, 258-259). In painting, Kandinsky and Marc echoed the same apocalyptic spirit in adopting the title The Blue Rider for their almanac, the prospectus of which began: "today art is moving in a direction of which our fathers would never have dreamed. We stand before the new pictures as in a dream and we hear apocalyptic horsemen in the air" (Kandinsky and Marc 1979, 252). Marc's sense of an historical turning point involving an apocalyptic struggle between an old world that was dying and a new one struggling to be born was conveyed in his painting Fighting Forms. [Fig. 3.] Richard Cork says of this painting, "despite his belief in the affirmative consequences of destruction, this strangely feverish picture indicates that Marc felt overwhelmed by a sense of havoc ahead" (1994, 28). In February 1914, Marc's foreword to the planned second volume of The Blue Rider confirmed his mood of anticipatory dread: "the world is giving birth to a new time; there is only one question: has the time now come to separate ourselves from the old world? Are we ready for the vita nuova? This is the terrifying question of our age" (Kandinsky and Marc 1979, 260).

\section{The Great War}

When war came in 1914, many artists and intellectuals embraced it as the apocalypse they had anticipated and the opportunity for liberation and renewal for which they hoped. Otto Dix was one of them. Dix himself confessed that "the war was a hideous thing, but there was something tremendous about it too. I couldn't afford to miss it" (Biro 2014, 110). He served for four years in a machine gun detachment on the western front. Franz Marc volunteered for service in an artillery regiment. In his letters from the front, he insisted that the war inspired his creativity. "Without the war, none of these ideas would be "thinkable," he wrote, "and for one thing, they would not even exist" (my translation, 1996, 56). While confessing that "never has such a desire to die or such a thirst for sacrifice taken hold of humanity as it has today," Marc held to the belief that the sacrifice would result in cultural redemption: "but the dead are indescribably happy. If no poet or no music emerges from this war, then none will exist ever again" (my translation, 1996, 81). Max Beckmann, too, although he did not serve in the front lines, got as close to them as he could, serving as a medical orderly at Ypres and on the eastern front. The war, he wrote in his diary on 23 May, 1915, "is in and of itself a manifestation of life, like sickness, love, or lust. And just as I consciously and unconsciously 
pursue the terror of sickness and lust, love, and hate to their fullest extent - so I'm trying to do now with this war. Everything is life, wonderfully changing and overly abundant in invention. Everywhere I discover deep lines of beauty in the suffering and endurance of this terrible fate" (Buenger 1997, 173). In Britain, the artist Paul Nash (and his brother John), the cartoonist Bruce Bairnsfather and the poet Edward Thomas joined the London Regiment of the Territorial Army, better known as the Artists' Rifles. In France, too, the poets Guillaume Apollinaire and Charles Péguy, as well as the painters André Mare, Georges Braque and Fernand Léger, were among those who volunteered for active service. Nor were musicians deaf to the call to arms. Arnold Schoenberg, denouncing the decadence of his French and Russian rivals, declared that the war would teach those "mediocre kitschmongers" a lesson (Ross 2007, 72). One of those rivals, Maurice Ravel, saw service as a truck driver. Although eventually invalided out of the army with dysentery, Ravel did at least see front-line service. Schoenberg's service, on the other hand, was limited to playing in a military orchestra (Ross 2007, 73; McAuliffe 2014, 306, 316).

Whether or not they signed up for military service, avant-garde artists, writers and musicians were eager to put their talents to work in the service of their respective countries' war efforts. The total nature of the war made it a bitter contest between cultures: a crusade on behalf of civilization against barbarism, as the Allies imagined it, and on behalf of the deep spiritual values of Germanic "Kultur" against the shallow materialism of Anglo-French "civilization," as the Germans imagined it. A sign of the times was the "Appeal to the World of Culture!" of 4 October 1914 made by 93 German intellectuals and artists, in which they denied the charges that the German army had committed atrocities in Belgium (Jelavich 1999, 44-45). This mobilization of culture implied a repudiation of the international connections that had made the European avant-garde such a rich and diverse community during the years before 1914. Max Beckmann provided an elegiac acknowledgement of this internationalism, writing, "I don't shoot at the French, I have learned so much from them. Nor at the Russians, Dostoyevsky is my friend" (Weissbrich 2014, 42). Harry Kessler, despite his official position orchestrating the production of German war propaganda, also found himself overcome by nostalgia for his cosmopolitan past as he mournfully reflected upon the damage likely to be done to his beloved cultural monuments of Paris by German long-range guns in the spring of 1918: "NotreDame, Ste-Chapelle, the Bibliothèque Nationale, so much that is refined, beautiful, irreplaceable, can be struck by chance" $(2011,825)$. That such sentiments were no longer in vogue after 1914 is illustrated by the fate of the Swiss artist, Ferdinand Hodler, who was swiftly ejected from the Berlin Secession, the Munich Secession 
and from the League of German Artists for joining other Swiss artists in protesting the destruction of cultural monuments, notably Rheims Cathedral (Kramer 2007, 28). The repudiation of internationalism after 1914 had lasting consequences. One of the chief casualties of the war's heightened cultural nationalism was French Cubism. Falsely condemned as "the German style" by critics, Cubism fell into disrepute. In 1915, Tony Tollet gave a lecture in Lyons entitled On the Influence of the JudeoGerman Cartel of Parisian Painting Dealers on French Art. Tollet elucidated a conspiracy theory to the effect that German art dealers "had imposed works stamped with German culture - Pointillist, Cubist, and Futurist, etc., - on the taste of our snobs [...]. Everything - music, literature, painting, sculpture, architecture, decorative arts, fashion, everything - suffered the noxious effects of the asphyxiating gases of our enemies" (Silver 1989, 8). Cubism's most famous exponent, the Francophile Spanish artist Picasso, sought an acceptably "latin" form of expression, choosing Ingres as the model for his war-time portraits. Cultural chauvinism also extended to the world of music. The National League for the Defence of French Music sought to ban the performance of works by German and Austrian composers, an initiative that was courageously resisted by Maurice Ravel and Claude Debussy (Richard Strauss was another musician who resisted the pressure of his peers, declining to sign the Manifesto of the Ninety-Three (McAuliffe 2014, 307; Ross 2007, 72-73).

The war did at least bring London, Paris, Rome and St. Petersburg (renamed Petrograd because it sounded less Germanic) closer together. Berlin, on the other hand, was thrown back on its own resources. The war had the effect of making Berlin culture more Germanic at the same time as it heightened its cultural significance as capital of the German Reich. As Stefan Goebel writes, "in wartime, the Prussian capital matured into the hub of cultural work in Germany; the war marked a turning point in the cultural history of the city overlooked in most accounts of Berlin's meteoric rise in the legendary 1920s" $(2007,187)$. Berlin's distance from the front intensified the need for patriotic exhibitions to represent the war to its population. In the spring of 1916, the Royal Academy of Arts in Berlin put 665 paintings by war artists on display (Weissbrich 2014, 46). Nail monuments, such as the giant figure of Hindenburg erected in Königsplatz, symbolically linked the blood sacrifice of soldiers at the front with the financial sacrifice of civilians whose donations gave them the right to hammer a nail into the monument. Such exhibitions had their counterparts in allied cities. In London in 1917, "tank banks" roamed the city, providing entertainment and soliciting donations, and in December 1919, 925 works by British war artists commissioned by the government were put on display at the Royal Academy (Wood 2014, 58). 
Nevertheless, only in Berlin was there a full scale "War Exposition" opened to the public. In the first four months of 1916, 500,000 people visited this display in the Zoological Gardens. Highlighting the technology of war, including heavy guns, mortars and vehicles, the exposition also featured a display on military medicine. In many ways, as Stefan Goebel points out, Berlin's War Exposition of 1916 was the antithesis of the Paris Universal Exposition of 1900, replacing the "trophies of civilization" with "the trophies of war and violence" $(2007,147)$.

The enthusiasm of artists for the war did not long survive the encounter with reality. Save perhaps for a few Italian Futurists, nearly all artists who experienced the war were sooner or later repelled by that experience. Some, of course, died with their illusions intact. That was the fate of August Macke, killed in September 1914. Franz Marc was also killed, in March 1916, by which time the war had for him long since lost its allure. "The world, many millennia old, has just enriched itself by its bloodiest year," he wrote to his wife on the first day of 1916, "it is frightful to think of it; and all that for NOTHING" (my translation, 1996, 150). Those who survived also experienced a change of heart. When Max Beckmann arrived in Flanders in the spring of 1915, he was brimming with enthusiasm. "For me the war is a miracle," he wrote, "even if a rather uncomfortable one. My art can gorge itself here” (Buenger 1997, 159). On May 4, having bolstered their courage with a bottle of champagne and another of red wine, Beckmann and a friend "went for a walk in the grenade fire" as if it were a walk in the rain. For a moment this satisfied his longing for ultimate experiences: "standing there in the middle between life and death gave me a delirious, almost evil sense of joy" (Buenger 1997, 165). Later the same day, however, having witnessed the suffering of the wounded and the dying in a front-line first aid station, as well as attending a funeral while under enemy fire, Beckmann confessed, "now for the first time, I've had enough" (Buenger 1997, 165). His written descriptions of the front evoke a mirror image of the modern city-scape. "Unforgettable and strange," he wrote of his first visit to the front lines. "In all those holes and sharp trenches. Those ghostly passageways and artificial forests and houses. That fatal hissing of the rifle bullets and the roar of the big guns. Strangely unreal cities, like lunar mountains, have emerged there.” (Buenger 1997, 163.) In June, he penned a description of Ypres: "I saw Ypres appearing like a mirage in the hot mists of the distance. Monstrous sulfurous yellow craters from explosions, over them the pale violet, hot sky, and the cold, rose-colored skeleton of a village church. Saw the entire strangely flat chain of Ypres's heights; it has in it something of the majestic barrenness and desertion of death and destruction. No more isolated house skeletons and destroyed churches - instead, entire plateaus 
of house skeletons, and wide, desolate plains thick with crosses, helmets, and churned up graves" (Buenger 1997, 175). It was descriptions like this that informed Beckmann's most important war-time painting. His unfinished Resurrection, as Jay Winter writes, is "anything but triumphal." Depicting his war-time companions "emerging from the long night of war into an uncertain day, lit by a dying sun," Beckmann's painting is devoid of hope in the future: "brooding on the disaster rather than on the better days to come" (1995, 166-167).

Otto Dix was another artist whose war experience destroyed his faith in the war as a salutary, life-renewing crisis. Dix's corpus of post-war paintings and etchings is the most devastating critique of the war and its consequences produced by any artist. One of those images, Skat Players (1920), [Fig. 4] helps to provide an insight into the nature of the artists' disillusionment and the way in which the war had affected their perceptions of modernity. Dix's painting is an unsympathetic portrayal of disabled veterans who, while still wearing the trappings of the military institution that was responsible for their mutilation, continue to function only through the aid of mechanical contrivances: ear trumpets, wooden legs, metallic jaw-bones, and so on. Where flesh ends and mechanical contrivance begins is anything but clear. Stephen Forcer writes, "Dix's image speaks for itself: the card-playing figures in the painting have passed through what Winston Churchill called 'gigantic agencies for the slaughter of men by machinery' and the same age of technological 'development' that allowed armies to increase the killing power of munitions has also afforded grotesquely innovative ways of patching up the soldiers' injuries" $(2014,87)$.

Dix's work encapsulated a view of the war and its consequences that he shared with other artists and intellectuals: that modern technology, far from accomplishing the triumph of humanity and civilization, had been the very agent of their demise. Fernand Léger wrote that the war had made human beings into unconscious slaves of machines: "individual action is reduced to a minimum. You pull the trigger on a gun and you fire without seeing. You hardly act. You no longer have the intoxication of action and you still have, even more than before, the danger of death [...]. In sum, we have come to this, human beings acting unconsciously and making machines act; we are very close to abstraction" (emphasis in the original, my translation, 1990, 22). Léger was one French artist, at least, who remained true to Cubism. His 1917 painting of The Card Game resembles Dix’s Skat Players both in terms of its subject - soldiers or ex-soldiers playing cards - and in terms of its indictment of a mechanized war and its dehumanizing effects. Léger's soldiers are reduced to a chaotic jumble of tubular metal fragments. Like Beckmann's, 
Léger's attitude toward the war was one of appalled fascination. "It is something like an immense cemetery where innumerable grave-diggers all dressed the same mechanically kill and bury a little bit more every day," he wrote in one of his letters (my translation, 1990, 53). In another, his Cubist imagination shades into Surrealism. "I adore Verdun," he wrote. "There are at Verdun completely unexpected subjects designed to make my Cubist spirit rejoice. For example, you find a tree with a chair perched upon it. Supposedly sensible people would treat you as an idiot if you presented them with a painting composed in this way. However all you have to do is copy. Verdun authorizes all pictorial fantasies" (my translation, 1990, 72). The writer Drieu la Rochelle shared Léger's insight into the ways in which the war had transformed the relationship between humans and machines. "Modern war," wrote Drieu in his 1934 novel, The Comedy of Charleroi, "is a maleficent revolt of the matter enslaved by man" (my translation, 1934, 88). Men, he said, had been dehumanized and vanquished by "this modern war, this war of iron and not of muscles. The war of science and not of art." He warned that "it is necessary for man to master the machine which surpassed him in this war and which now surpasses him in peace" (my translation, 1934, 75-76).

That medical science was implicated in this twin process of mechanization and dehumanization was recognized both by practitioners and by observers. Georges Duhamel referred to himself ironically as "a good worker in human flesh" (my translation, Duhamel and Duhamel 2008, 414) in describing the exhausting, production-line surgery in which he was employed by the French army. In a short story entitled The Fleshmongers, he described a medical review board indifferently approving men in varying states of health fit for front-line duty (1919, 121-134). George Grosz's Fit for active service, [Fig. 5] in which a doctor in thrall to the military authorities is shown approving a skeleton for service in the army, would have been a perfect illustration for Duhamel's story (Duhamel 2005, 279). A similar complicity in the abuse of military and medical power was described in the musical vein by Alban Berg, whose unhappy wartime service gave rise to the modernist opera, Wozzeck, which described the descent into homicidal madness of a soldier persecuted by the combined efforts of a captain and a doctor (Ross 2007, 72-79). Another story by Duhamel, entitled simply Civilization, described the autoclave - a machine for sterilizing instruments - as the beating heart of a mobile surgical unit. The machine, he wrote, was "raised like a monarch on a sort of throne." It "filled the universe with its strident cry," he continued, while medical personnel "seemed to execute, harmoniously, a religious dance, a sort of severe and mysterious ballet" around it (my translation, 2005, 385-388). In this 
passage Duhamel evoked, like Henry Adams, the religious awe inspired by modern technology. But for Duhamel the machine he described was not so much aweinspiring as it was awful. Although recognizing that the ambulance was a force for good, Duhamel marvelled that a machine of such complexity was necessary "to nullify a bit of the immense harm done by the age of machines" (my translation, $2005,389)$. The conclusion to his reflection on the autoclave was scarcely a comforting one: "I say to you, civilization is truly not in this object any more than in the shiny instruments of the surgeon. Civilization is not in any of that terrible junk; and if it is not in the heart of man, well! It is nowhere" (my translation, 2005, 392). Duhamel's wartime reflection was not so very far from that of Hermann Bahr as the latter sought to provide a definition of Expressionism: "so, brought very near the edge of destruction by 'civilization,' we discover in ourselves powers which cannot be destroyed. With the fear of death upon us, we muster these and use them as spells against 'civilization.' Expressionism is the symbol of the unknown in us in which we confide, hoping that it will save us" (Bahr 1925, 88). Both the Frenchman and the German had arrived at the same insight at about the same time, that man "has become the tool of his own work [...], since he serves the machine" (Bahr 1925, 83) and that any hope of salvation must come from within.

\section{Conclusion}

What Duhamel and Bahr gave voice to was nothing less than a loss of faith. The naïve faith in modernity expressed by Henry Adams in 1900 and by Robert Delaunay in 1913 was dealt a severe blow by the Great War. As Philipp Blom writes, the forces of modernity that had been apparent before 1914 and which had determined the shape of the Great War would continue to transform the world after 1918, "but now the optimism about technology had been crushed, the idea of a glorious and uninterrupted march of progress lay in ruins, and faith in the values underpinning society had been profoundly shaken" $(2015,8-9)$. It is this loss of faith that provides the context for the dystopian films representing the enslavement or defeat of humans by machines such as Fernand Léger's Surrealist Ballet Mécanique (1924) and Fritz Lang's Expressionist masterpiece, Metropolis (1926).

Despite the severing of international cultural connections during the war years, the common experience of the war ensured that Europe's artists and intellectuals evolved along parallel lines during the conflict. There was, of course, a refuge for those whose internationalism was so deeply rooted that they refused to abandon it in 1914. Figures as diverse as Romain Rolland and Lenin sought asylum in 
Switzerland. It was also in Switzerland that the Dada movement was born. The participants in this movement, which defined itself by its rejection of the war, were self-consciously cosmopolitan in their outlook. This was exemplified by the name change of one of its leading exponents, Helmuth Herzfeld, who took the name John Heartfield in 1916. Otto Dix, the most famous of Germany's anti-war painters of the 1920s and 1930s, exhibited his work alongside that of the Dadaists. His most famous works also betray international influences, most notably his painting Flanders, inspired by the writing of Henri Barbusse. Indeed, despite their obvious differences, during the postwar years both French Surrealists and German Expressionists were inspired by the Dada movement and, in their unique and inimitable ways, expressed their rejection of the war, as well as of the values that had made it possible. Luc Albert Moreau was not a Surrealist and probably would have objected to being categorized as belonging to any particular movement. Severely wounded during the war, he spent the postwar period obsessively painting images of his dead comrades. Like other artists, relatively few, who had the courage to tackle this theme, Moreau abandoned Modernism for a realism reminiscent of Courbet. Nevertheless, his depictions of French soldiers as dehumanized trench warriors [Fig. 6] bear a striking similarity to an etching by Dix of German stormtroopers [Fig. 7]. In short, German Expressionism was a movement that was, like all the other cultural "isms" of the day, deeply implicated in the debates over the meaning of modernity that reached a critical moment in the Great War of 1914-1918. As Stephan Wiese writes, "once the history of the avant-garde within Modernism is perceived in this way as a simultaneous process, Expressionism loses its national prefix" (1988, 122). Like other contemporaneous movements elsewhere, German Expressionism sought to come to terms with the human implications of the machine age. Ultimately, the experience of the war confirmed and accentuated its pessimism. The apocalyptic hopes of a new world and a new man of the pre-war generation gave way to the morbidity of the postwar generation. Faith in the transformative power of modern machines or of the human will did not entirely vanish, but for the time being at least, it had moved to the margins of cultural and political life.

\section{References}

Adams, Henry. 1918. The Education of Henry Adams: an Autobiography. Boston: Houghton and Mifflin Company.

Agathon (Massis, Henri and Alfred de Tarde). 1919. Les Jeunes Gens d'Aujourd'hui [The Young People of Today]. Paris: Librairie Plon. 
Bahr, Hermann. 1925. Expressionism. London: Frank Henderson.

Beckmann, Max. 2002. Écrits [Writings]. Paris: Ecole Nationale Supérieure des Beaux-Arts.

Biro, Matthew. 2014. Otto Dix: War and Representation. In Nothing but the Clouds Unchanged: Artists in World War I, eds. G. Hughes and P. Blom, 108-117. Los Angeles: Getty Research Institute.

Blom, Philipp. 2015. Fracture: Life and Culture in the West, 1918-1938. London: McClelland and Stewart.

Buenger, Barbara Copeland. 1997. Max Beckmann: Self-Portrait in Words: Collected Writings and Statements 1903-1950. Chicago and London: The University of Chicago Press.

Cork, Richard. 1994. A Bitter Truth: Avant-Garde Art and the Great War. New Haven and London: Yale University Press.

Drieu la Rochelle, Pierre 1934. La Comédie de Charleroi [The Comedy of Charleroi]. Paris: Gallimard.

Duhamel, Georges. 1919. Civilization. New York: The Century Company.

Duhamel, Georges. 2005. Vie des martyrs et autres récits des temps de guerre [Life of Martyrs and other Wartime Stories]. Paris: Omnibus.

Duhamel, Georges and Blanche Duhamel. 2008. Correspondance de Guerre, 1914-1919 vol. 2, (Janvier 1917 - Mars 1919) [War Correspondence, 1914-1919 vol. 2, (January 1917 - March 1919)]. Paris: Honoré Champion Éditeur.

Eliel, Carol S. 1989. The Apocalyptic Landscapes of Ludwig Meidner. In The Apocalyptic Landscapes of Ludwig Meidner, ed. C.S. Eliel, 11-61. Los Angeles: Los Angeles County Museum of Art and Prestel-Verlag.

Emmerson, Charles. 2013. 1913: In Search of the World Before the Great War. New York: Public Affairs.

Forcer, Stephen. 2014. Beyond Mental: Avant-garde Culture and War. In Aftermath: Legacies and Memories of War in Europe 1918-1945-1989, eds. N. Martin, T. Haughton and P. Purseigle, 85-107. Farnham: Ashgate Publishing Limited.

Gentile, Emilio. 2011. L'Apocalypse de la Modernité: La Grande Guerre et I'homme nouveau [The Apocalypse of Modernity: The Great War and the New Man]. Paris: Aubier.

Goebel, Stefan. 2007. Exhibitions. In Capital Cities at War: Paris, London, Berlin 1914-1919. A Cultural History, vol. 2, eds. J. Winter and J.-L. Robert, 143-187. Cambridge: Cambridge University Press. 
Jelavich, Peter. 1999. German culture in the Great War. In European Culture in the Great War: The Arts, Entertainment and Propaganda, eds. A. Roshwald and R. Stites, 33-57. Cambridge: Cambridge University Press.

Kandinsky, Wassily and Franz Marc, eds. 1979. The Blaue Reiter Almanac. New York: The Viking Press.

Kessler, Harry. 2011. Journey to the Abyss: the Diaries of Count Harry Kessler 1880-1918. New York: Alfred A. Knopf.

Kramer, Alan. 2007. Dynamic of Destruction: Culture of Destruction: Culture and Mass Killing in the First World War. Oxford: Oxford University Press.

Léger, Fernand. 1990. Une Correspondance de Guerre à Louis Poughon [War Correspondence with Louis Poughon]. Paris: Les Cahiers du Musée Nationale d'Art Moderne.

Large, David Clay. 2000. Berlin. New York: Basic Books.

Levenstein, Harvey. 1998. Seductive Journey: American Tourists in France from Jefferson to the Jazz Age. Chicago and London: University of Chicago Press.

Marc, Franz. 1996. Lettres du Front [Letters from the Front]. Paris: Fourbis.

McAuliffe, Mary. 2014. Twilight of the Belle Epoque: The Paris of Picasso, Stravinsky, Proust, Renault, Marie Curie, Gertrude Stein and Their Friends through the Great War. Lanham: Rowman and Littlefield.

Ross, Alex. 2007. The Rest is Noise: Listening to the Twentieth Century. New York: Picador.

Roters, Eberhard. 1989. The Painter's Nights. In The Apocalyptic Landscapes of Ludwig Meidner, ed. C.S. Eliel, 63-92. Los Angeles: Los Angeles County Museum of Art and Prestel-Verlag.

Silver, Kenneth. 1989. Esprit de Corps: The Art of the Parisian Avant-Garde and the First World War 1914-1925. Princeton: Princeton University Press.

Vriesen, Gustav and Max Imdahl. 1967. Robert Delaunay: Light and Color. New York: Harry N. Abrams, Inc.

Wood, Jenny. 2014. Champs de bataille et nouvelle perspectives. Les artistes britanniques [Battlefields and New Perspectives. British Artists]. In Vu du front: représenter la grande guerre [From the Front: Representing the Great War], ed. Wanda Romanowski et al. 49-58. Paris: Somogy éditions d'art, Bibliothèque de documentation internationale contemporaine, Musée de l'Armée.

Weber, Eugen. 1986. Fin de Siècle. Cambridge, Massachusetts and London, England: The Belknap Press of Harvard University Press. 
Weissbrich, Thomas. 2014. Dans les tranchées et dans l'atelier. Les peintres de guerre allemands [In the Trenches and in the Workshop. German Wartime Painters]. In $V u$ du Front: Représenter la Grande Guerre [From the Front: Representing the Great War], ed. Wanda Romanowski et al. 41-48. Paris: Somogy editions d'art; Bibliothèque de documentation internationale contemporaine; Musée de l’Armée.

Wiese, Stephan von. 1988. Expressionism as an International Movement. In German Expressionism 1915-1925: the Second Generation, ed. Stephanie Barron, 117-123. Los Angeles: Los Angeles County Museum of Art.

Winter, Jay. 1995. Sites of Memory, Sites of Mourning: The Great War in European Cultural History. Cambridge: Cambridge University Press.

Wohl, Robert. 1994. A Passion for Wings: Aviation and the Western Imagination 1908-1918. New Haven and London: Yale University Press.

\section{List of Figures}

Figure 1. Robert Delaunay, L'équipe de Cardiff (Team of Cardiff). 1913. Oil on canvas. Bpk Bildagentur/Sammlung Moderne Kunst, Pinakothek der Moderne. Bayerische Staatsgemaeldesammlungen, Munich, Germany / Art Resource, NY. Figure 2. Max Beckmann, The Sinking of the Titanic, 1912. / Saint Louis Art Museum, Missouri, USA / Bequest of Morton D. May / Bridgeman Images / (c) Estate of Max Beckmann / SODRAC 2018.
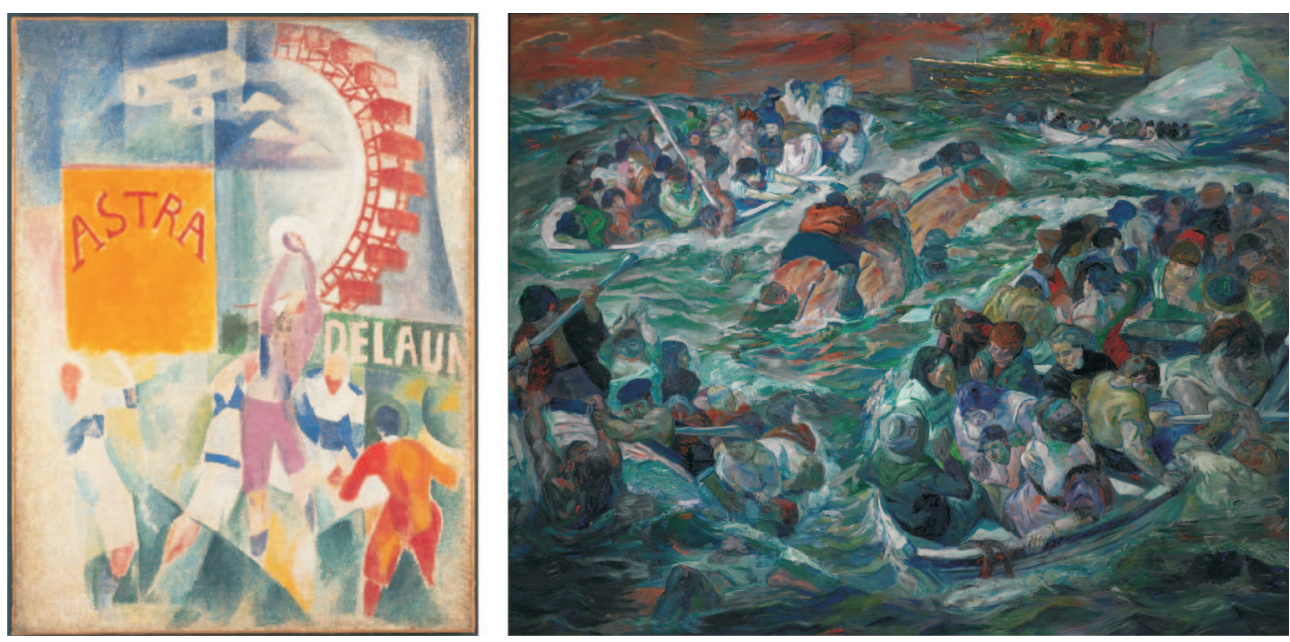
Figure 3. Franz Marc, Fighting Forms, undated. Bpk Bildagentur / Sammlung Moderne Kunst, Pinakothek der Moderne, Bayerische Staatsgemaeldesammlungen, Munich, Germany / Art Resource, NY.

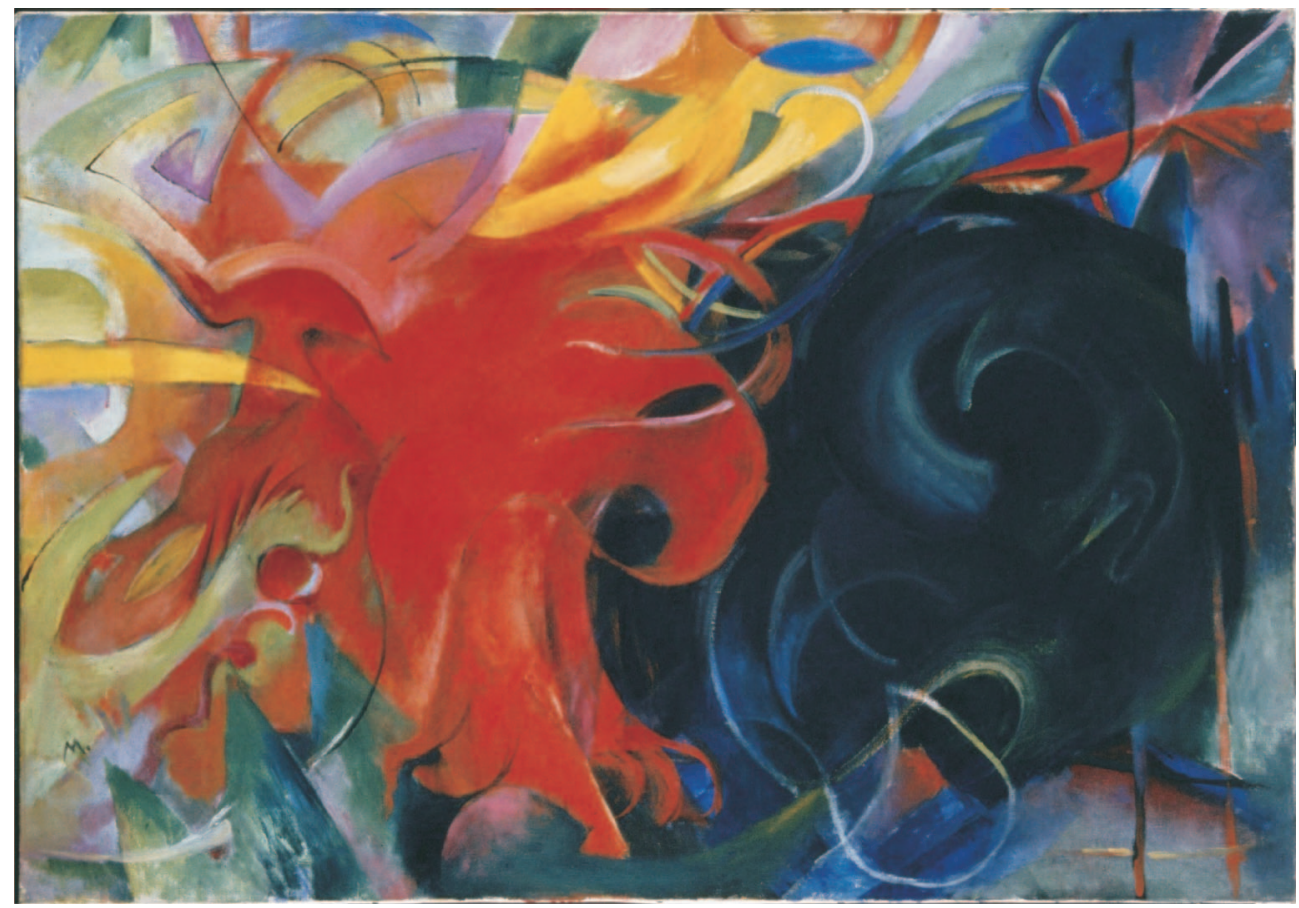


Figure 4. Otto Dix, Skat Players, 1920. Nationalgalerie, Staatliche Museen, Berlin, Germany. Photo Credit: Erich Lessing / Art Resource, NY / @ Estate of Otto Dix / SODRAC (2018).

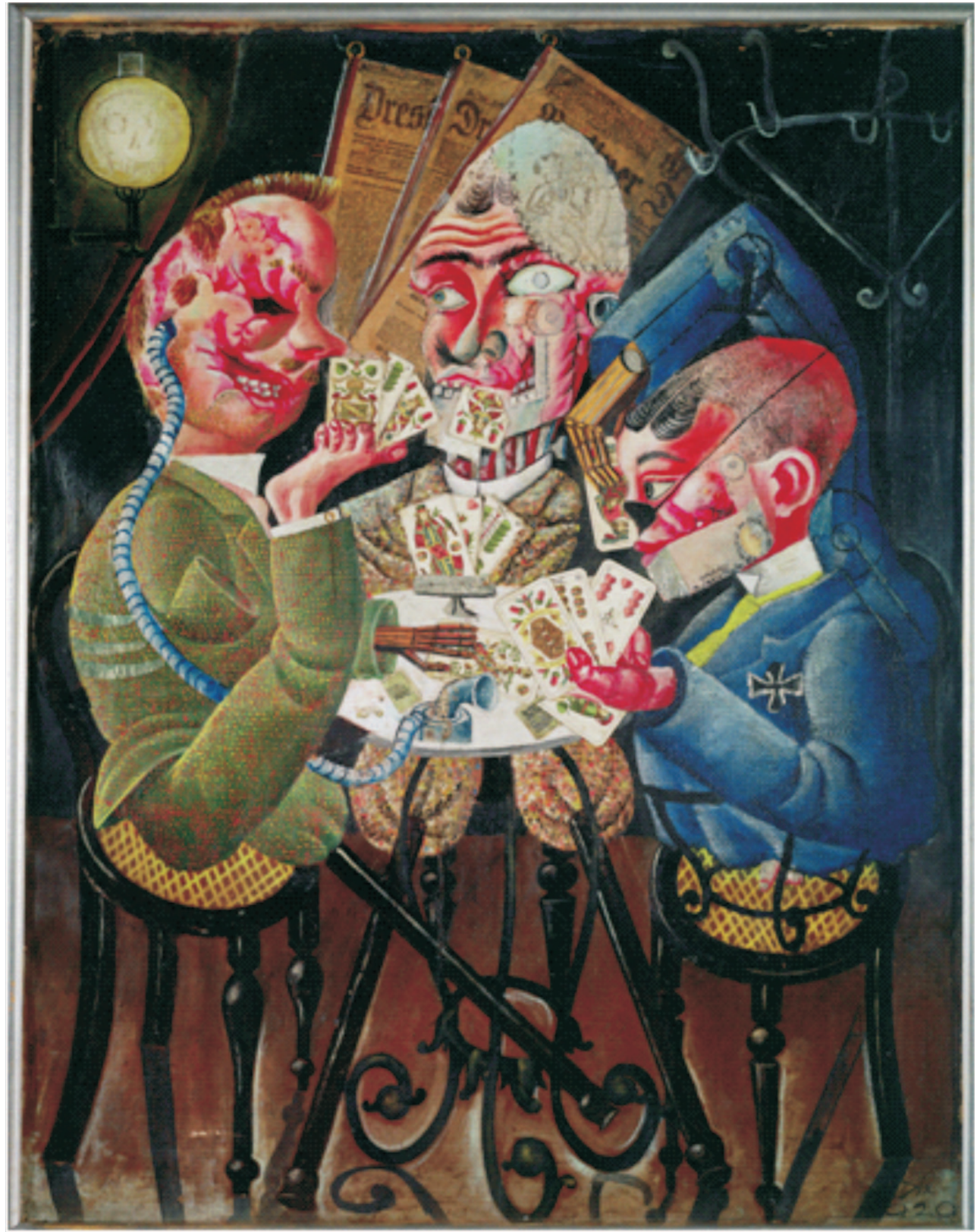


Figure 5. George Grosz, Fit for Active Service. The Museum of Modern Art, New York, NY, U.S.A. Photo Credit: Digital Image (c) The Museum of Modern Art/Licensed by SCALA / Art Resource, NY / @ Estate of George Grosz / SODRAC (2018).

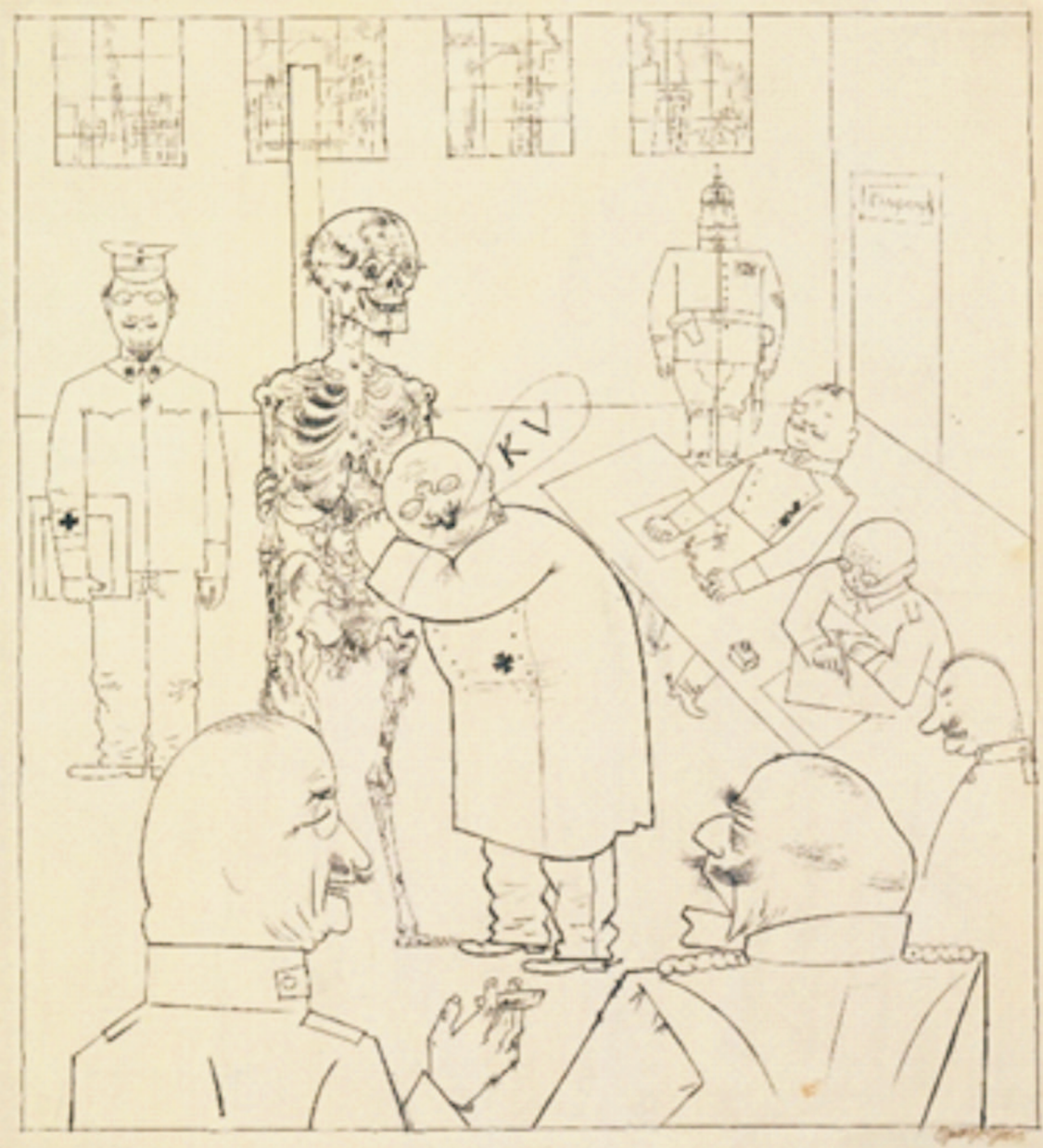


Figure 6. Moreau, Luc-Albert (1882-1948) Les gaz [Verdun 1914-1918]. Oil on canvas. 49 x 39.5 cm. (Collection BDIC, Nanterre: OR 969.). .

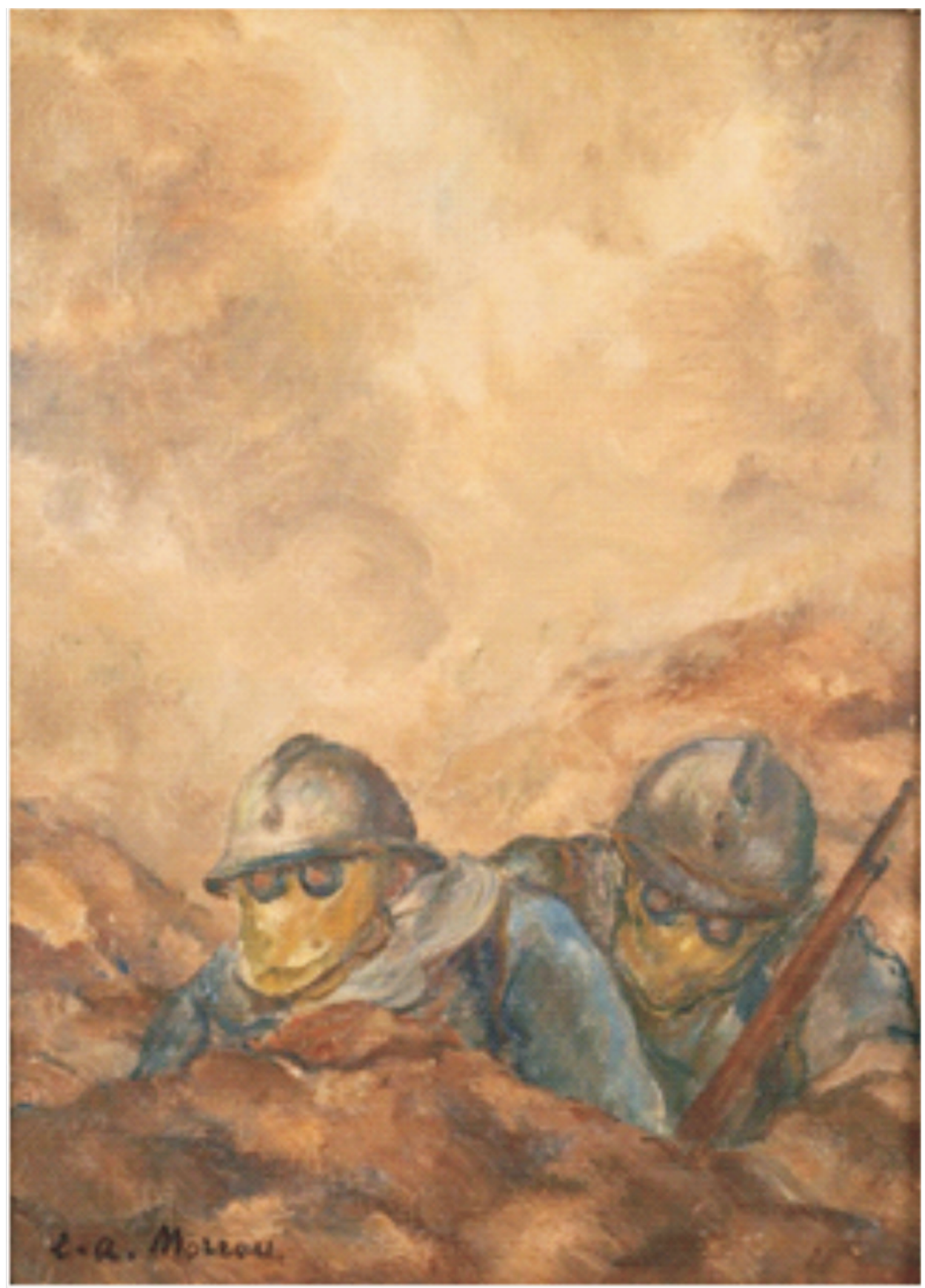


Figure 7. Otto Dix. 1924. Storm Troops Advancing under Gas. (From the series The War.) Print. Found in the collection of the Kunstsammlung Nordhein-Westfalen, Dusseldorf. HIP / Art Resource, NY / @ Estate of Otto Dix / SODRAC (2018)

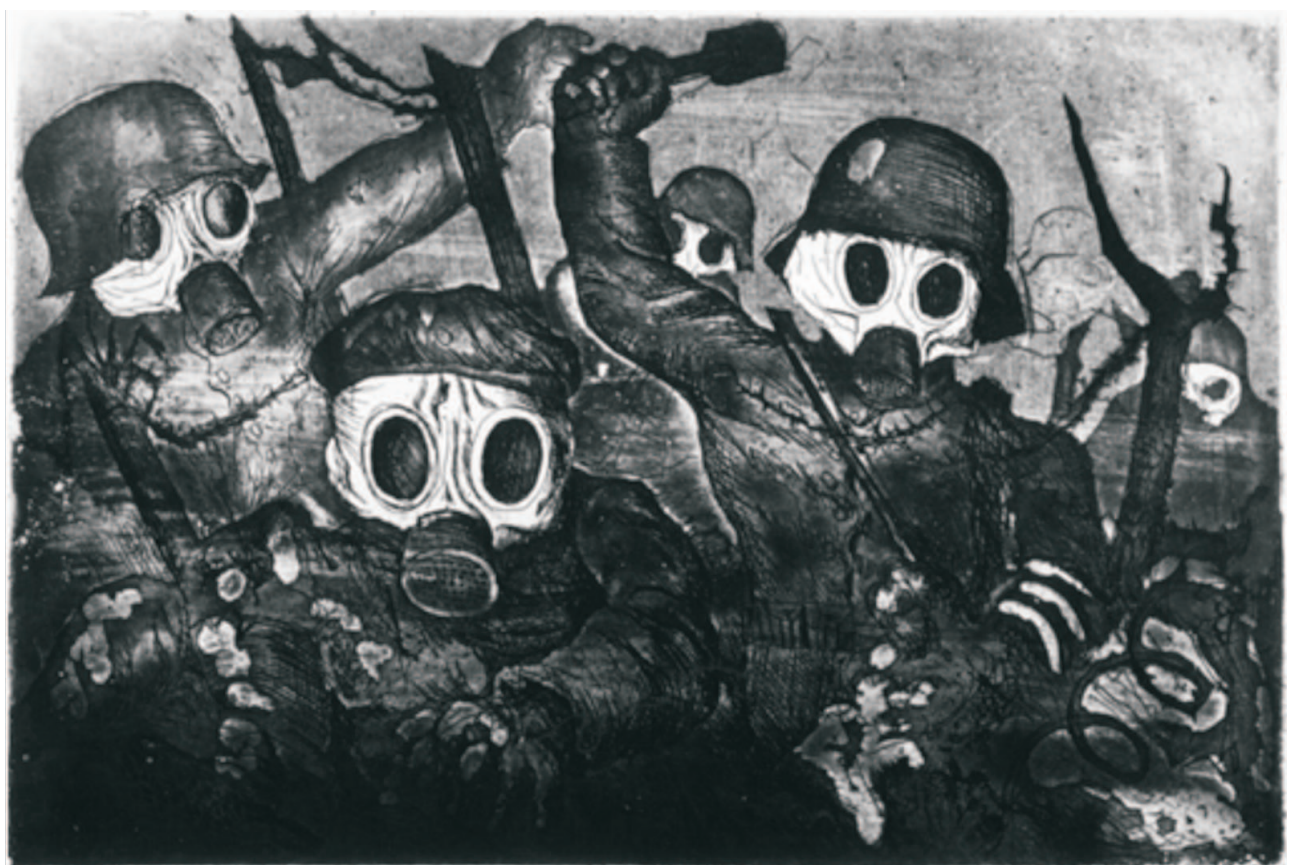

